\title{
The Analysis of Sanctions' Influence \\ on Russian Stock Market Based \\ on Sanction Index Development
}

\author{
Elena A. Fedorova ${ }^{a, b}$, Liubov E. Khrustova ${ }^{a, b *}$ \\ and Svetlana O. Musienko ${ }^{a}$ \\ ${ }^{a}$ Financial University under the Government \\ of the Russian Federation \\ 49 Leningradsky, Moscow, 125993, Russia \\ ${ }^{b}$ School of Finance, NRU HSE \\ 20 Myasnitskaya Str., Moscow, 101000, Russia
}

Anti-Russian sanctions have become one of the key factors, determining the state of the Russian national economics in recent years. Financial restrictions against companies and residents, which constrict the possibility of raising foreign funding and limit cooperation with abroad investors, have become one of the sanctions' types. Such events could not but affect the state of the Russian financial market. The aim of the work under discussion is to estimate the impact of anti-Russian sanctions on the Russian financial market from 2014 till 2018. In order to achieve the stated objective the authors developed a system of indexes that allow quantitatively showing the sanctions imposed against Russia by different foreign countries. The indexes were calculated not only for all restrictions in total, but also for sanctions imposed by different groups of countries (USA, European Union and other countries). In addition, the developed indexes make it possible to take into account the degree of particular sanctions' impact based on the level of the object under sanctions. The stated indexes' analysis in relation to the variation of MOEX index allowed establishing the high degree of dependence of the Russian financial market's dynamics on the imposed sanction restrictions and justifying the proposed approach to indexes' calculation.

Keywords: Russian financial market, sanctions, anti-Russian sanctions, sanctions' influence, sanctions' influence index.

The authors acknowledge the support provided by the Financial University under the Government of the Russian Federation through budget resources assigned for 2019.

Research area: economics.

(C) Siberian Federal University. All rights reserved

* Corresponding author E-mail address: khrustoval@yandex.ru

ORCID: 0000-0002-3381-6116 (Fedorova); 0000-0002-0884-2734 (Khrustova); 0000-0003-0348-8323 (Musienko)

This work is licensed under a Creative Commons Attribution-NonCommercial 4.0 International License (CC BY-NC 4.0). 
Citation: Fedorova, E.A., Khrustova, L.E., Musienko, S.O. (2019). The analysis of sanctions' influence on Russian stock market based on sanction index development. J. Sib. Fed. Univ. Humanit. Soc. Sci., 12(12), 2155-2169. DOI: 10.17516/1997-1370-0525.

\section{Introduction and Theoretical Framework}

Sanctions, used mainly as a tool for exercising political influence, nevertheless, have a significant impact on all aspects of the functioning of a country that is subject to established restrictions. Despite the fact that the achievement of the planned effect of the introduction of sanctions is discussed and disputed in the economic literature, the consequences of sanctions are tangible and require the implementation of decisions that correct various directions of public policy (Pape, 1997). The Russian-Ukrainian conflict and the annexation of Crimea to Russia served as the starting point for a long period of imposing sanctions on Russia and taking retaliatory measures. At the moment, almost any event that has occurred on the international political arena can be the reason for starting the next stage in the development of sanction measures. Anti-Russian sanctions imposed from the beginning of 2014 to June 2018 had serious economic consequences for our country, including the Russian financial market.

The financial market turned out to be particularly affected by the events that occurred due to the fact that many stages of the imposition of sanctions against individuals and legal entities implied restricting access to foreign sources of financing, which forced companies to seek new ways to attract investment and led to significant structural changes. The relevance of the study lies in the need to develop methodological tools to take into account the impact of anti-Russian sanctions on the dynamics of the Russian financial market.

The issues of the impact of the imposed sanctions on various sectors of the economics in recent years have received wide coverage in economic and legal literature in connection with the growing geopolitical tension in the world and the phased introduction of a set of restrictive measures by leading countries in relation to each other. Nevertheless, some studies on this subject have been carried out by Russian and foreign scientists before. The variety of possible forms of restrictions introduced, as well as their multidimensional impact on various aspects of state activity, stimulated the development of a large number of studies on this issue in various directions. Table 1 shows some of the existing works on the issue of sanctions and their consequences, including works related to the analysis of the impact of sanctions on the Russian financial market. 
The relationship of the influence of economic sanctions of some states in relation to others is studied in detail in the economic literature. Sanctions as a tool of economic and political interaction are studied generally from the point of view of their expediency and effectiveness (Hufbauer, Oegg, 2003; Smeets, 2018), social consequences (Lv, Xu, 2017; Shahabi et al., 2015) The Russian-Ukrainian conflict provoked the emergence of a large number of new studies examining the problem of imposing sanctions from various points of view. Among the key areas are the analysis of the general impact of sanctions on the economy of Russia and other countries, the assessment of the role of Russia in the international political arena after the imposition of sanctions, the analysis of the impact of sanctions on certain segments of the economy (in particular, the financial market).

Currently, studies related to assessing the impact of sanctions through the construction of various sanction indexes are actively developing. These indexes are built on the basis of various approaches and methodologies, and their main goal is to quantify the impact of the imposed sanctions on various aspects of the economics of individual countries. The study by Dreger C. et al, who, on the basis of the developed sanctions index, explained the dynamics of the Russian rubble against the dollar and the euro, oil prices and a number of other macroeconomic indicators can be an example of such a work (Dreger et al., 2016).

The aim of this work was to analyse the impact of anti-Russian sanctions on the changes in the Russian financial market on the basis of the developed authors' indexes. It was the financial market that was chosen as the object of study, since this segment is the most sensitive to all the changes that are taking place, including the information covered in print and electronic publications. The analysis was carried out on the basis of constructing a system of indexes that take into account the nature of the sanctions introduced, as well as using a text analysis methodology that allows considering the impact of news texts on financial market fluctuations.

\section{Methods and Empirical Study Base}

Initially, the authors constructed a system of cumulative sanction indexes characterizing the gradual increase in the impact of the restrictions introduced on various aspects of the national economics of Russia. These cumulative indexes were built on the basis of the methodology proposed by the authors Dreger C. et al, and allowed evaluating the feasibility of their construction and the possibility of practical use. In general, the authors analyse the impact of economic sanctions imposed 


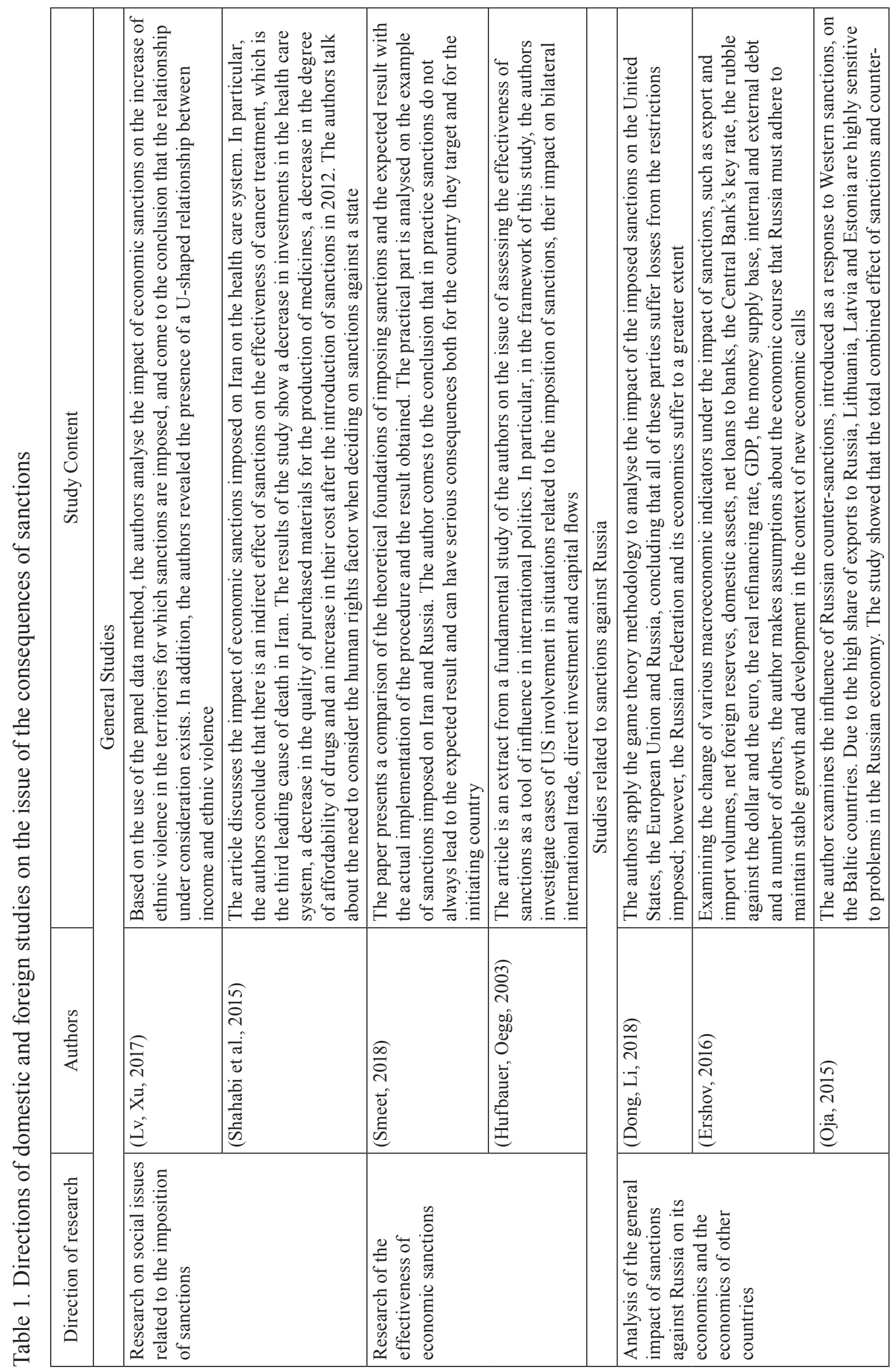




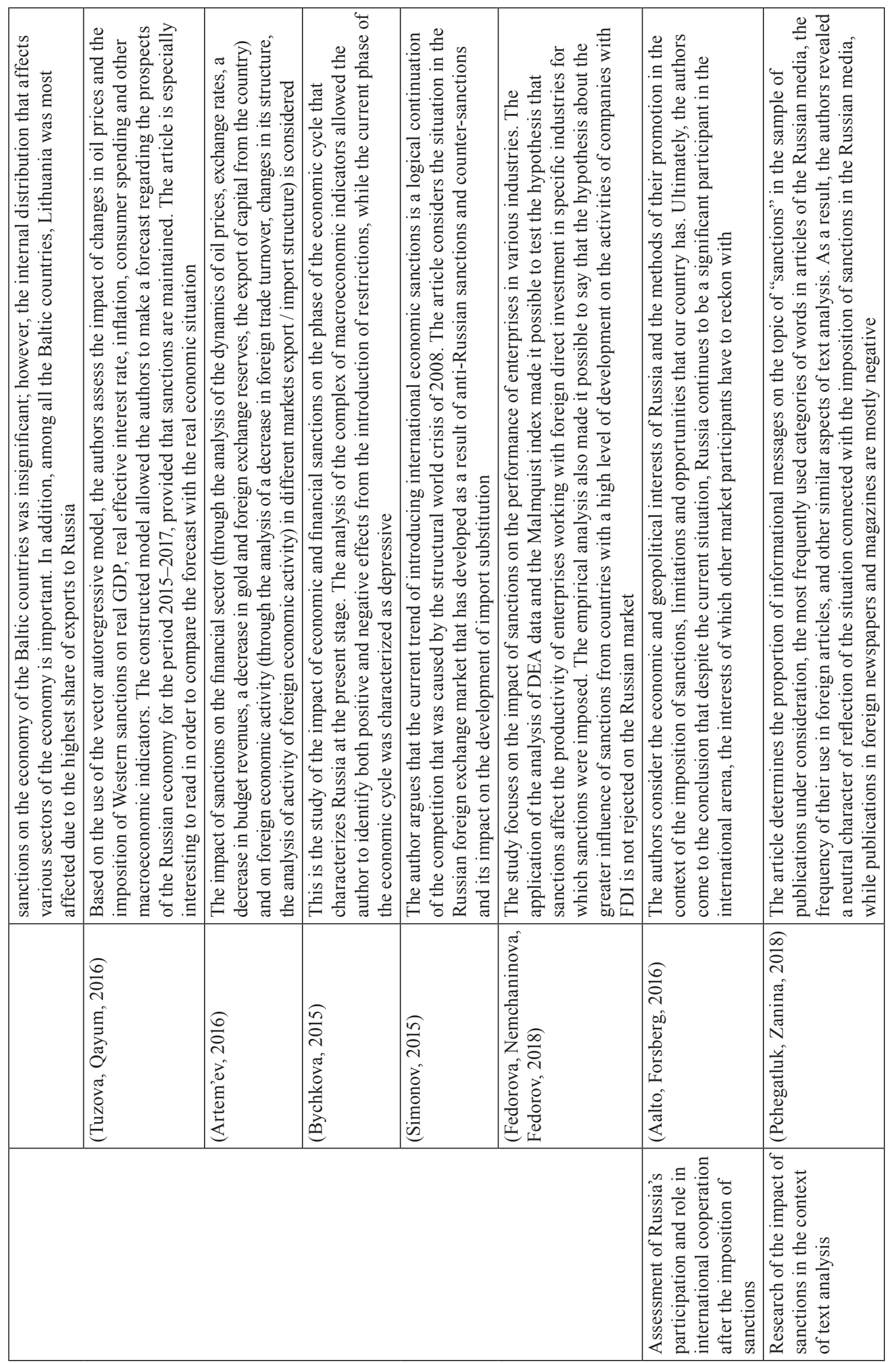




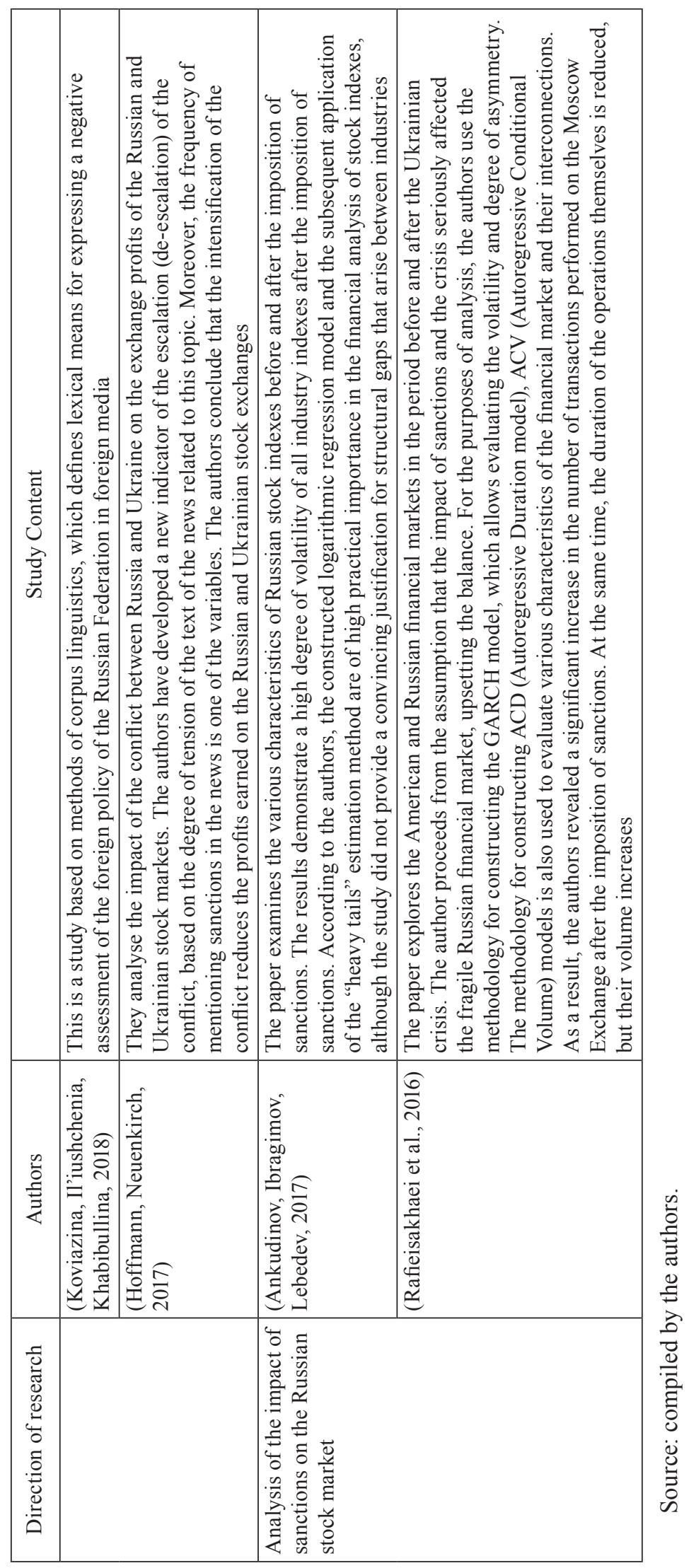


on Russia after the conflict in Ukraine, as well as the impact of the changes in oil prices on fluctuations in the exchange rate of the Russian rubble. The assessment of macroeconomic indicators and the imposed sanctions, combined with the use of text search and analysis tools in relation to media reports, allowed the authors to justify the fluctuations of the Russian currency, relating it to the imposition of sanctions and changes in raw material prices (Dreger et al., 2016).

Following the methodology for constructing the cumulative index of Dreger C. et al., we divided the entire set of sanctions into three categories depending on the degree of significance. The significance of sanctions was determined by the following characteristics of the objects against which they were introduced: individuals, legal entities, industries. The author's contribution consists in the development of a methodology for constructing a cumulative index through the study of the country effect, which was taken into account by constructing cumulative sanction indexes for the United States, the European Union, and other countries in aggregate.

The authors collected complete information about all cases of the imposition of sanctions against Russia for the period from March 17, 2014 to July 31, 2018. The fact of imposing restrictions was indicated by dummy variable 1 . Sanctions against citizens, organizations and industries were assigned weight depending on their significance (1, 2 and 3, respectively). If sanctions of various categories were introduced on the same day, based on the assumption that their total effect was enhanced, the weights of these sanctions were also added up when constructing the index.

It should be noted that when constructing the indexes, the dates of extension of sanctions were not taken into account. Reports on the extension of sanctions certainly have an impact on the financial market, however, when the index was formed, these events could not be evaluated as new restrictions against one of the categories of entities.

The lack of application of the indexes in question is hidden in the methodology of their construction. The indexes are cumulative in nature, and, consequently, their values are constantly growing, responding to new sanction restrictions imposed on Russia. The use of these indexes in order to analyse the impact of sanctions on the financial market is limited, since it can lead to distorted results due to the constantly upward dynamics of their values.

In connection with the identified shortcoming, based on the application of the text analysis methodology the authors constructed two new indexes characterizing the intensity of coverage of sanctions imposed against Russia in foreign media. The authors 
proceeded from the assumption that the dynamics of the financial market indicators directly depends on the number of references to Russia and the restrictions connected with it in the foreign media.

The SAN0 and SAN1 indexes were built on the basis of the methodology of the advanced thematic modelling algorithm, which supposes time-optimized searches and matrix operations with an array of news data and relevant sentiment. The SAN0 index included the number of media references to the words "sanctions" and "economic sanctions"; the expanded SAN1 index was calculated based on the words "sanctions", "economic sanctions", "restriction", "ban", "blockade", "block", "barrier", "import ban".

To build indexes, the Thomson Reuters database was used, which served as a source of news texts. For the purposes of analysis, the authors considered news for the period from 2013 to 2018 (test period of 2015-2018). The total sample of news texts amounted to more than 10 million news from various sources accredited by Thomson Reuters, the main ones of which are the New York Post, CNN, Breitbart, Reuters, Fox, Atlantic, The Washington Post, and Buzzfeed.

The daily dynamics of the constructed indexes was analysed in conjunction with the changes in the Moscow Exchange index (MICEX index, MOEX index) and the US dollar against the Russian rubble (RATE), which were selected as indicators of changes in the Russian financial market. As a result, the most significant indicators were identified that determine the dynamics of key indicators of the Russian financial market.

\section{Results of Analysis}

The dynamics of the constructed cumulative sanction indexes (general, USA, EU and other countries) are presented in Fig. 1.

The overall cumulative sanctions index is constantly growing due to the constant introduction of new sanctions against Russia, but the pace of its change moves over time. Rapid growth was observed in 2014, since it was the first year of the international confrontation (from March 2014 to March 2015) that was marked by a large number of restrictions imposed almost daily on our country. In March 2015, the graph of the general cumulative index became flatter. One can also note a pronounced rise from June to December 2016, associated with the systematic sequential expansion of sanction lists by various countries.

Comparing the indexes formed for the USA and the countries of the European Union, it can be seen that in the period until the fall of 2016, the sanctions imposed by the European 


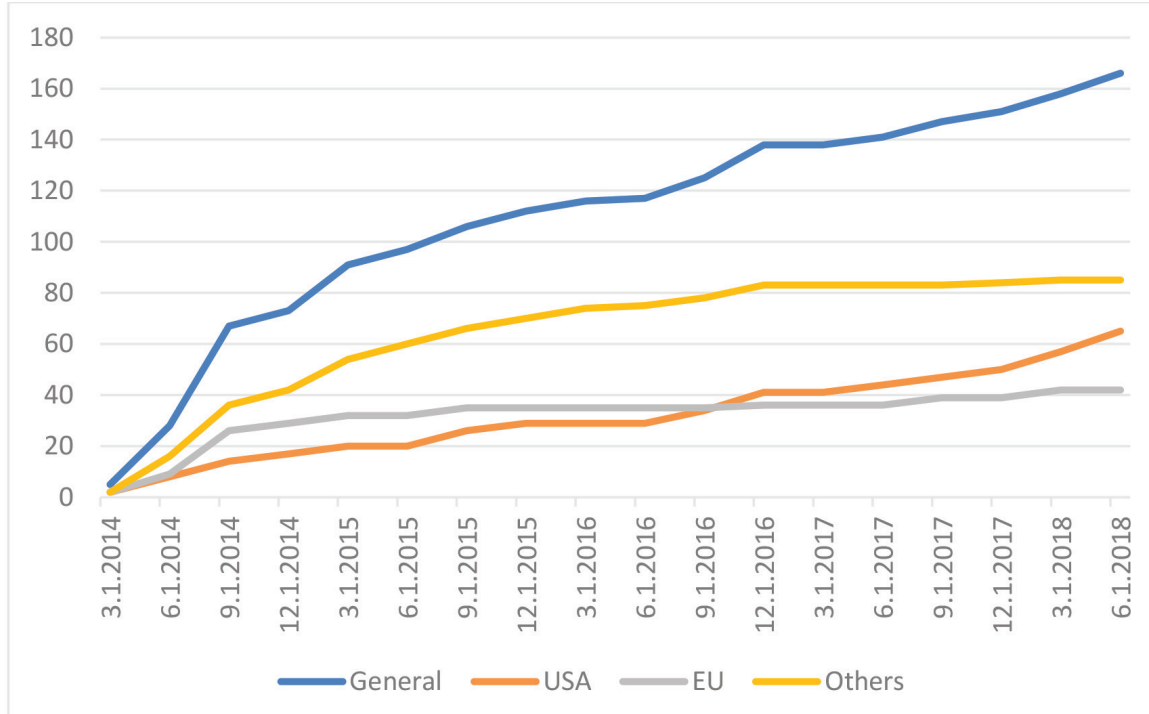

Fig. 1. Sanctions cumulative index in dynamics

Union had a greater influence (greater total weight). However, subsequently, the curve reflecting the sanctions activity of the EU countries has practically no ups, while the cumulative index of US sanctions began to grow rapidly. Such a trend can be explained by the political events that took place in the USA during the period under review, namely, the election situation, the election of a new president and his subsequent confrontation with a number of senior officials and political figures. The curve reflecting the influence of all other countries that were not included in the first two categories, in our opinion, is not representative enough, since the generalization of a large number of countries into a single category leads to a significant increase in the cumulative index solely due to an increase in the number of dates associated with the imposition of sanctions. Thus, this index takes on a higher value only because of the scale of its coverage.

The indexes built for the USA, EU countries and other countries do not give a total result obtained when constructing the overall cumulative index. This is due to the fact that often the same date is marked by the imposition of sanctions by several states simultaneously. In such situations, it can be difficult to single out the influence of restrictions imposed by a particular country, especially if they are identical in content. That is why the same dates and assessments of the impact of sanctions fall into the calculation of several indexes simultaneously.

The dynamics of the constructed SAN0 and SAN1 indexes has an upward trend too (Fig. 2). 


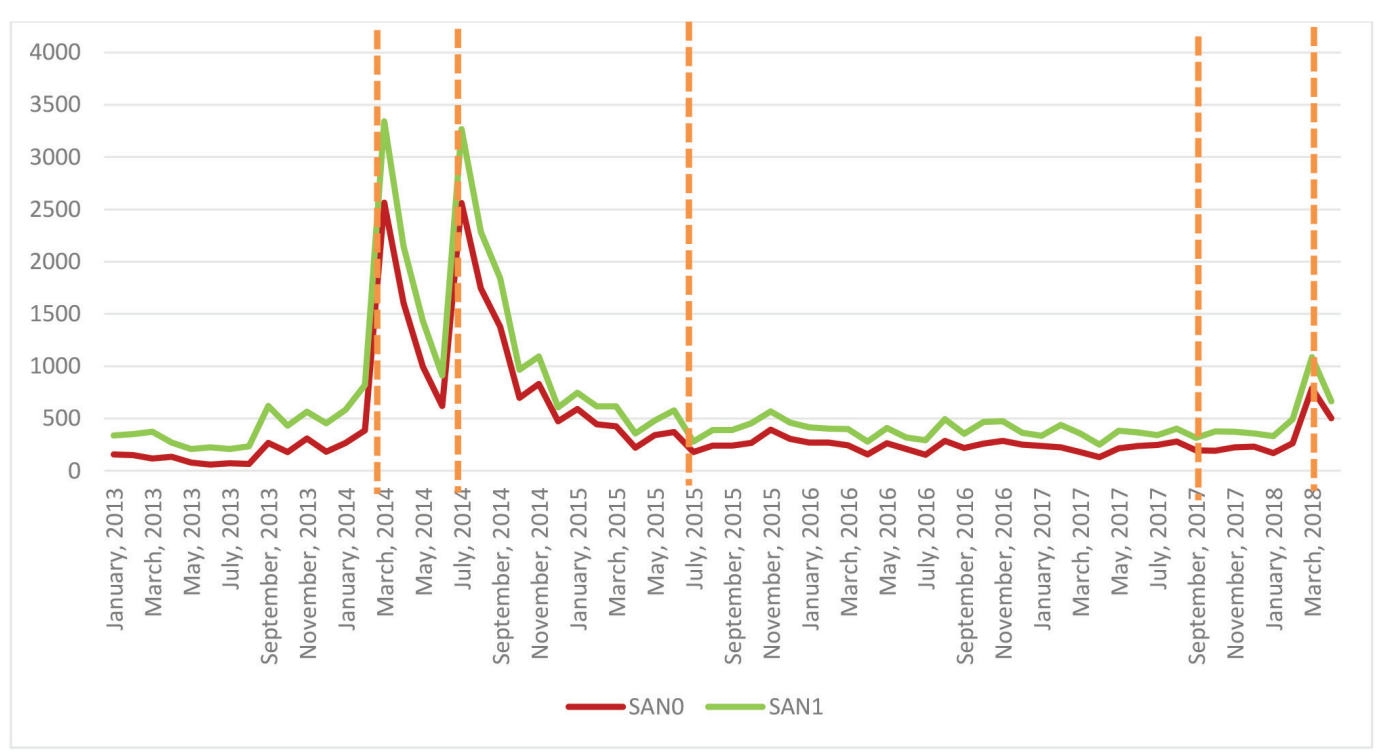

Fig. 2. Dynamics of changes in the developed sanction indexes (SAN0 and SAN1) for the period from January 2013 to March 2018

In order to study the impact of the developed anti-Russian sanctions indexes on the Russian stock market, we analysed the relationship between the changes in the Moscow Exchange Index (MOEX), the US dollar exchange rate against the Russian rubble and the three indexes covered in the work, constructed using different methodologies. The relationship was investigated using a causal testing methodology.

The correlation matrix of the considered indicators is presented in Table 2.

Table 2. Correlation matrix of developed indexes and financial market indicators

\begin{tabular}{|c|c|c|c|c|c|}
\hline & MOEX & RATE & SAN0 & SAN1 & INDEX \\
\hline MOEX & 1.000000 & 0.531639 & -0.425972 & -0.424022 & 0.914456 \\
\hline RATE & 0.531639 & 1.000000 & -0.470042 & -0.477962 & 0.647189 \\
\hline SAN0 & -0.425972 & -0.470042 & 1.000000 & 0.990634 & -0.477624 \\
\hline SAN1 & -0.424022 & -0.477962 & 0.990634 & 1.000000 & -0.476544 \\
\hline INDEX & 0.914456 & 0.647189 & -0.477624 & -0.476544 & 1.000000 \\
\hline
\end{tabular}

The presented correlation matrix allows us to see that the SAN0 and SAN1 indexes developed by the authors have a negative relationship with both the MICEX 
index and the US dollar against the Russian rubble. In other words, a decrease in the number of references to Russia and anti-Russian sanctions in the texts of foreign media leads to an increase in the MICEX index, as well as an increase in the dollar against the rubble. It can also be noted that the cumulative sanctions index proposed by the authors has a close positive relationship with the MICEX index, which confirms the hypothesis that it is not practical to use it. Such a relationship suggests that an increase in the number of anti-Russian sanctions contributes to the growth of the MICEX index, which contradicts the logic of judgments and the real situation.

The application of the methodology for constructing a standard regression with respect to the considered indicators made it possible to confirm the findings. The authors revealed that the cumulative sanctions index is not significant in the process of modelling the dynamics of the MICEX index. At the same time, the developed SAN0 and SAN1 indexes, reflecting the coverage of Russia and the imposed sanctions in foreign media, showed high significance.

The MICEX index model was built on the assumption that the effect of coverage of the introduction of sanctions restrictions in foreign media on the financial market is not immediate; it takes some time before the financial market indicators begin to respond to the information received. The consistent construction of models with different lags for SAN0 and SAN1 indicators revealed that the MICEX index responds to information presented in foreign media with a delay of 10 days. The results are presented in Table 3.

Table 3. Building a model of the dependence of the MICEX index on the developed indexes SAN0 and SAN1

\begin{tabular}{|c|c|c|c|c|}
\hline & Coefficient & Std. Error & t-Statistic & Prob. \\
\hline RATE & 2.301799 & 0.272358 & 8.451364 & 0.0000 \\
\hline SAN0(-10) & 0.385350 & 0.231589 & 1.663934 & 0.0963 \\
\hline SAN1(-10) & -0.448982 & 0.180336 & -2.489695 & 0.0129 \\
\hline @TREND & 0.554858 & 0.006411 & 86.55064 & 0.0000 \\
\hline C & 1282.315 & 14.95289 & 85.75702 & 0.0000 \\
\hline MA(1) & 0.881599 & 0.012083 & 72.96127 & 0.0000 \\
\hline R-squared & \multicolumn{4}{|c|}{0.965103} \\
\hline
\end{tabular}

All factors unaccounted for explicitly in the econometric model accumulate in a random term et. In classical econometrics, this would mean the need to search and take 
into account such factors, but in this case, since the MICEX index is a time series, this is not necessary. We take into account the fact that unaccounted factors also have the inertia property, which means that it is enough to try to take into account the lagged structure of a random term, so 1 lag is added to the equation. A linear trend is also added to the equation.

Summing up, we can conclude that the cumulative sanction index proposed in the economic literature, despite the presence of positive characteristics, is not applicable in order to measure the effect of the sanctions introduced on changes in the financial market. To achieve this goal, it is advisable to use the anti-Russian sanctions coverage indexes proposed by the authors in foreign mass media, which have demonstrated high significance in the process of modelling changes in the MICEX index, taken as a key indicator reflecting the state of the Russian financial market.

\section{Conclusion}

Sanctions as a tool of economic and political influence have a significant impact on all aspects of the functioning of the country, including the financial market. One of the current research areas is the development of indexes that allow quantifying the impact of the imposed sanctions on various macroeconomic indicators.

The authors of this work analysed the dynamics of changes in the Russian financial market under the influence of restrictions imposed by foreign countries. The Moscow Exchange Index was taken as a dependent variable. To quantify the impact of restrictions, a system of indexes was developed, from various sides, characterizing the ongoing sanctions policy. The first group of indexes reflected the cumulative effect of all sanctions measures taken against Russia. As a result of the study, it was found out that despite wide coverage and a high degree of reliability, these indexes cannot be used in analysing the dynamics of the financial market and have a low degree of significance in the process of modelling the MICEX index.

The second group of indexes, developed by the authors, characterized the impact of sanctions through an assessment of Russia's coverage and anti-Russian sanctions in foreign media. Based on the modern methodology of text analysis, these indexes have demonstrated a high degree of significance and an adequate relationship with the Moscow Exchange index. It was revealed that references to Russia and antiRussian sanctions in foreign media with a lag of 10 days have an impact on the dynamics of the Russian financial market, which must be taken into account in the process of modelling its behaviour. Thus, the proposed indexes make it possible to 
quantitatively measure the impact of anti-Russian sanctions on the performance of the Russian financial market.

\section{References}

Aalto, P., Forsberg, T. (2016). The structuration of Russia's geo-economy under economic sanctions. In Asia Europe Journal, 14 (2), 221-237.

Ankudinov, A., Ibragimov, R., Lebedev, O. (2017). Sanctions and the Russian stock market. In Research in International Business and Finance, 40, 150-162.

Artem'ev, N.V. (2016). Ekonomicheskaia bezopasnost': ispytanie sanktsiiami. Finansovyi sektor i vneshneekonomicheskaia deiatel'nost' [Economic Security: Assay by Sanctions. Financial sector and International Economic Activity]. In Vestnik Moskovskogo universiteta MVD Rossii [Bulletin of Moscow University of Interior Ministry of the Russian Federation], (3), 217-224.

Bychkova, L.S. (2015). Vliianie ekonomicheskikh i finansovykh sanktsii na tsiklicheskoe razvitie ekonomiki Rossii [Influence of Economic and Financial Sanctions on Cyclic Development of Russian Economy]. In Novyi universitet: seriia «Ekonomika i pravo» [New University: Economics and Law series], (7), 5-8.

Dong, Y., Li, C. (2018). Economic sanction games among the US, the EU and Russia: Payoffs and potential effects. In Economic Modelling, 2-12. Article in press.

Dreger, C., Kholodilin, K. A., Ulbricht, D., \& Fidrmuc, J. (2016). Between the hammer and the anvil: The impact of economic sanctions and oil prices on Russia's rubble. In Journal of Comparative Economics, 44 (2), 295-308.

Ershov, M.V. (2016). What Economic Policy Does Russia Need Under the Sanctions? In Problems of Economic Transition, 58 (3), 181-202.

Fedorova, E.A., Nemchaninova, D.N., Fedorov, F. Yu. (2018). Kak sanktsii povliiali na effektivnost' raboty predpriiatii: otraslevoi aspekt [How sanctions influenced companies' efficiency: industrial aspect]. In Finansovaia analitika: problemy i resheniia [Financial analytics: problems and their solutions], (11), 87-101.

Hoffmann, M., Neuenkirch, M. (2017). The pro-Russian conflict and its impact on stock returns in Russia and the Ukraine. In International Economics and Economic Policy, 14 (1), 61-73.

Hufbauer, G.C., Oegg, B. (2003). Economic Sanctions: Public Goals and Private Compensation. In Chicago Journal of International Law, 4, 305-328.

Koviazina, M.A., Il'iushchenia, T.A., Khabibullina, S.B. (2018). Sredstva vyrazheniia otritsatel'noi otsenki pri opisanii sanktsionnoi politiki zapadnykh stran 
$\mathrm{v}$ otnoshenii Rossii i rossiiskikh otvetnykh sanktsii v tekstakh britanskikh setevykh SMI: korpusnoe issledovanie [Means of negative characterization expression while describing sanction policy of Western countries in relation to Russia and its countersanctions in British net media texts: corpus-based research]. In Politicheskaia lingvistika [Political linguistics], (2), 61-67.

Lv, Z., Xu, T. (2017). The effect of economic sanctions on ethnic violence of target states: A panel data analysis. In The Social Science Journal, 54 (1), 102-105.

Oja, K. (2015). No milk for the bear: the impact on the Baltic states of Russia's counter-sanctions. In Baltic Journal of Economics, 15 (1), 38-49.

Pape, R.A. (1997). Why Economic Sanctions Do not Work. In International security, 22 (2), 90-136.

Pchegatluk, S.K., Zanina, O.P. (2018). Problema mezhdunarodnykh sanktsii v zarubezhnykh i rossiiskikh SMI: sotsiologicheskii analiz [Problem of international sanctions in foreign and Russian media: sociologic analysis]. In Teoriia i praktika obshchestvennogo razvitiia [Theory and practice of society development], (5), 31-35.

Rafieisakhaei, M., Barazandeh, B., Moosavi, A., Fekri, M., \& Bastani, K. (2016). Supply and demand dynamics of the oil market: A system dynamics approach. In The 34rd International Conference of the System Dynamics Society.

Shahabi, S., Fazlalizadeh, H., Stedman, J., Chuang, L., Shariftabrizi, A., \& Ram, R. (2015). The impact of international economic sanctions on Iranian cancer healthcare. In Health Policy, 119 (10), 1309-1318.

Simonov, V.V. (2015). Antirossiiskie sanktsii i sistemnyi krizis mirovoi ekonomiki [Russian sanctions and systematic crisis of world economy]. In Voprosy ekonomiki [Economics Issues], (2), 49-68.

Smeets, M. (2018). Can economic sanctions be effective? In WTO Staff Working Paper, available at: https://www.econstor.eu/bitstream/10419/176768/1/1016551045.pdf

Tuzova, Y., Qayum, F. (2016). Global oil glut and sanctions: The impact on Putin's Russia. In Energy Policy, 90, 140-151. 


\title{
Анализ влияния санкций \\ на российский финансовый рынок \\ на основе разработки санкционных индексов
}

\author{
Е.А. Федорова ${ }^{\text {a, }, ~}$, Л.Е. Хрустова ${ }^{\text {a, },}$, С.О. Мусиенко \\ ${ }^{a}$ Финансовый университет при Правительстве РФ \\ Россия, 125993, Москва, пр. Ленинградский, 49 \\ ${ }^{6}$ Школа финансов НИУ ВШЭ \\ Россия, 101000, Москва, ул. Мясницкая, 20
}

Антироссийские санкиии признаны одним из ключевых факторов, определяющих состояние российской национальной экономики в последние годы. Разновидностью санкций стали финансовые ограничения, вводимые против компаний и физических лии, сужающие возможности привлечения иностранного финансирования и ограничивающие взаимодействия с зарубежными инвесторами. Подобные события не могли не отразиться на состоянии российского финансового рынка. Целью представленной работы является определение влияния антироссийских санкций на финансовый рынок России в период с 2014 по 2018 год. Для достижения поставленной цели авторами были разработаны индексы, позволяющие количественно выразить вводимые против России санкции со стороны различных иностранных государств. При этом индексы были рассчитаны не только для всей совокупности ограничений, но и отдельно для санкиий, вводимых различными блоками стран (США, Европейским союзом и прочими странами). Построенные индексы также позволяют учесть степень влияния конкретных санкционных мероприятий исходя из уровня объекта, против которого были введены ограничения. Рассмотрение указанных индексов во взаимосвязи с изменением индекса ММВБ позволило установить существование высокой степени зависимости динамики российского финансового рынка и вводимых санкиионных ограничений и обосновать предлагаемый подход к расчету индексов.

Ключевые слова: российский финансовый рынок, санкиии, антироссийские санкиии, влияние санкций, индекс влияния санкций.

Статья подготовлена по результатам исследований, выполненных за счет бюджетных средств по государственному заданию Финуниверситета 2019 г.

Научная специальность: 08.00.00 - экономические науки. 